\title{
The Life-Idealism of Michel Henry
}

\section{Steven Nemes}

Journal of French and Francophone Philosophy - Revue de la philosophie française et de langue française, Vol XXIX, No 1-2 (2021) pp 87-108

\author{
Vol XXIX, No 1-2 (2021) \\ ISSN 1936-6280 (print) \\ ISSN 2155-1162 (online) \\ DOI 10.5195/jffp.2021.969 \\ www.jffp.org
}

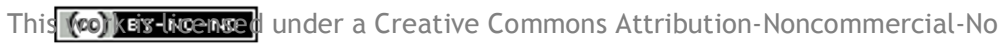
Derivative Works 3.0 United States License.

\section{ULIS D-Sunk}

This journal is operated by the University Library System of the University of Pittsburgh as part of its D-Scribe Digital Publishing Program, and is co-sponsored by the University of Pittsburgh Press 


\title{
The Life-Idealism of Michel Henry
}

\author{
Steven Nemes \\ Grand Canyon University
}

The purpose of this essay is to exposit and interpret some of the essential contours of the phenomenology of Christianity proposed by Michel Henry in dialogue with his theological critics. These critics are numerous, but many of their critiques can be united under a single theme: the accusation of Gnosticism. One reads in them that Henry is a Gnostic monist, or rather a dualist, or rather both, or perhaps even a pantheist; that he blurs the distinction between the human being and God; that he denies or ignores the world or the creation; or that he denies the traditional Christian conception of faith in favor of a kind of quasi-mystical gnōsis; and so on. The conviction motivating the composition of the present work is that all such criticisms are ill-founded, indeed that the substance of Henry's phenomenology of Christianity, such as it is formulated in his Christian "trilogy," is not Gnostic at all. ${ }^{1}$ The truth is rather that Henry proposes a kind of "life-idealism" according to which (i) life is the foundation of the possibility of the world; (ii) life assumes a visible, external representation (viz., the empirical body) in its activities in the world; and (iii) the meaning of the world is that it is the arena in which life pursues the goal of its own perfection and growth.

The discussion will proceed as follows: first, by addressing the distinction between world and life; second, by formally stating Henry's "lifeidealism"; and third, by responding to the various accusations of Gnosticism from Henry's theological critics. ${ }^{2}$

\section{World and Life}

The most significant contribution brought by Michel Henry to twentieth century phenomenology is the insight that there are two distinct domains of appearance. This is a point he fervently maintains contrary to the "ontological monistic" presuppositions not only of Husserl and Heidegger but also of much of the Western philosophical tradition in general, which only recognized one mode of appearance- that of the object in the world. ${ }^{3}$ In good 
phenomenological manner, this is a proposal which can be confirmed by every person through careful reflection upon his or her own experience. On the one hand, there is the domain of the "world," this vast "Outside" in which objects show themselves as other before the gaze of intentional consciousness in the form of irreal representations subject to the constant flow of the Heraclitean flux of time. In this itself-apparent stage or horizon or environment or milieu of visibility appear objects of all kinds, not only actual concrete objects such as this cat or that dog, but even abstract or ideal objects, such as the truths of mathematics and geometry. ${ }^{4}$ Thus, the mode of appearance of objects is "worldly." On the other hand, there is the domain of "life," in which a living subjectivity characterized by its own proper ipseity constantly experiences itself in various modes, whether suffering or joy or whatever. In the world, there appears an object, such as an empirical body with its numerous visible properties-for example, masculine, tall, somewhat muscular, somewhat fat, with a mustache, of a certain weight, of a certain shape, of a certain determinable age, of a certain ethnic ancestry, possessing a particular chemical constitution, and so on. But the life of this man which is being described-more specifically, that subjective experience that he has of himself as a living being, indeed which he himself is-strictly speaking is not itself worldly, nor is it directly perceptible in the world, since it appears only to him.

World and life are thus two distinct domains of appearance, each with its proper mode of manifestation. The appearance of the world is characterized by intentional ekstasis, whereas that of life can be described as enstatic and nonintentional. In the world are found objects, whereas in life oneself is found. Now, Henry makes a further contribution to the phenomenological tradition when he argues, contrary to what would seem to be a natural objectivistic tendency, that life is in fact more foundational than the world. Henry's argument in Material Phenomenology is as follows:

Life is thus not a something, like the object of biology, but the principle of every thing. It is a phenomenological life in the radical sense where life defines the essence of pure phenomenality and accordingly of being insofar as being is coextensive with the phenomenon and founded on it. For what could I know about a being that could not appear? Because life is the original phenomenalization at the core of being and thus what makes it be, one must reverse the traditional hierarchy that subordinates life to being under the pretext that it would be necessary for life itself "to be." As such, the living would delineate only a region of being, a regional ontology. But the being to which life is submitted is Greek being, the being of a worldly being, which would be thought and conceived starting on the basis of the world. Such a being would still only be a dead being or rather a 
nonbeing, if the ek-stasis in which its proper phenomenality unfolds were not auto-affected in the immediacy of the pathos of Life. So Life always founds what we call "being" rather than the contrary. ${ }^{5}$

The argument can perhaps be understood thus. A thing is called a "being" because it appears within the horizon of the "Outside" of the world, i.e., because it fulfills an intention. But nothing could appear, and thus nothing could be a being, unless something could feel itself being appeared to. And to feel oneself being appeared-to is nothing other than to possess life, i.e., to experience oneself constantly. ${ }^{6}$ In this way, the world is defined with reference to life, whereas life is defined with reference to itself. As Karl Hefty comments, "There can 'be' things, real things imbued with real meaning, the world in all its wondrous diversity, only in life."

A similar argument is also found in this passage from Incarnation:

Every sensed body presupposes another body that senses it; every body that is seen presupposes a power of vision and the implementation, operation, or, as we would say, performance of this power... . So we are inevitably referred from a sensible, worldly body, which is an object of the world, to a body of another order entirely: a transcendental body endowed with the fundamental powers of seeing, sensing, touching, hearing, moving, and being movedand defined by these power. . . . A subjective, transcendental body, giving and sensing the body given and sensed by it-every worldly, objective body. ${ }^{8}$

Once more the argument is rather clear. The seen empirical body presupposes a body which possesses the power of sight. But it is obvious that the operation of the power of sight is not itself seen. "Who has ever seen his own vision?"9 This is to say that the ekstatic intentionality involved in the seeing of a visible object presupposes the enstatic nonintentionality of selfaffection, or as Michael Kelly puts it: "intentionality presupposes selfawareness." 10 The transcendence and ekstasis associated with the world is thus founded upon immanence.

Now, if the world is founded upon life, there is also the question of the origin of the transcendental living self which each person is and to whom the world and its objects appear. Henry's argumentation on this point is very clear and, in many ways, reminiscent of classical theistic natural theology, ${ }^{11}$ despite his own criticisms of and opposition to the natural theological project in general. ${ }^{12}$

The most fundamental truth about any person is that he or she is a living self, whose life consists in the fact of his or her constantly experiencing herself as alive. Life is the fundamental ontological condition for Michel Henry. Now, 
he writes: "The most remarkable characteristic of our entire practical life is to act in every circumstance with such ease, in a freedom so great that it pays no attention to the transcendental condition of the numerous actions it constantly accomplishes spontaneously." 13 Because of this ease, the transcendental self "deems itself finally to be the source and foundation of its very being. Thus the greatest illusion of all: this I, insuperably passive toward itself, always already given to itself in life, placed in it independently of its own willing, has become in its own eyes an all-powerful Subject, master of itself, as it were absolute principle of its condition living, of its self, of all its capacities and its talents." ${ }^{14}$ But it is at the same time obvious that no living human being is responsible for the fact of his or her being alive, but rather finds him- or herself always already having received life and thus his or her very self as a gift. ${ }^{15}$ No one could do anything to secure for him- or herself even a moment's life more, since every action a human being could perform would require the prior possession of life. Thus, "This powerlessness of humans, even within the actual exercise of their 'I can,' signifies their condition of sonship-the fact that each of their powers, that their self, that their lives are only given to themselves in the self-givenness of absolute Life."16 In this way, as Henry says in Words of Christ, there is a distinction and separation to be made between the finite living self and the absolute Life of God which is immanently present in each finite living self as that life which makes him or her to be alive. ${ }^{17}$ The human being is therefore alive because of God who is absolute Life. The human being is engendered in the absolute Life of God.

For Henry, this fact about the human being as a son of God engendered within the absolute Life of God is the fundamental teaching of Christianity. This also means further that the truth of Christianity is not a supernaturally revealed truth that would otherwise be inaccessible to reason. ${ }^{18}$ Rather, it is a truth about phenomenality and is thus immanently knowable:

Christ says to humans: you are the sons of God. "you have only one Father." Where is the referent of this assertion? In us. We are sons of God. God is Life and we are living beings. Are there living beings somewhere who do not carry life in themselves, who would not be carried by it? This is not a philosophical and speculative thesis. We feel and experience life in us as that in which we live, even when we feel and experience that we have not given this life to ourselves. The selfrevelation in which we are given and revealed to ourselves, is the Word [Parole] of Life, is its Word [Verbe]. Thus we are the irresistible proof of what the Word [Parole] speaks to us, there where it does not cease to speak our own life to us. Whoever hears this Word, where it speaks to us, forever hears the sound of his or her birth in him- or herself. It is to us that the Word says: "Today, I have engendered you" [Heb. 1:5]. ${ }^{19}$ 
So also, in I Am the Truth Henry writes that the truth of Christianity "concerns not what shows itself but the fact of self-showing, not what appears but the way of its appearing, not what is manifest but the pure manifestation, in itself and as such-or, to put it another way, not the phenomenon but phenomenality." 20 And this in turn implies that the human being is not ignorant of God:

\begin{abstract}
Yet, if God is Life ... we know what God is. We know it not via our thinking, according to the shaky reasons of an understanding which undertakes to reflect on God without knowing why and, trying to grasp some aspect of him, sees precisely nothing. We know it because we are living beings and because living beings are only living if they carry Life in themselves not as a secret unknown to them but as that itself which they experience without cease, as that in which they experience themselves, as their own essence and their very reality. If God is Life, then, as Meister Eckhart will say, the human being — this living being in the life which we each are-is "a human who knows God" (ein Gott wissender mensch). ${ }^{21}$
\end{abstract}

In this way, one can know what God is-indeed, even know Him. ${ }^{22,}{ }^{23}$ For Henry, then, the essential teaching of Christianity is eminently knowable. One could even say that it is known by all in principle, although very many, living under the illusion of the self-sufficiency of the "I Can," forget their condition as sons of God. ${ }^{24}$

\title{
Life-Idealism
}

In the arguments enumerated above, namely from Material Phenomenology and Incarnation, it would seem that Henry is able to establish the fundamentality of life relative to the world by delimiting the definition of the world to the fact of appearing. Otherwise, one could easily retort that the existence of the world or at least of the things which show themselves within it is independent of the fact of their appearing, so that the proposed subordination of world to life fails. ${ }^{25}$ In this sense, Henry proposes what might be called a kind of life-idealism.

It would be useful to clarify the meaning of this label. Henry's philosophy is here called an idealism because it grants ontological priority to consciousness and subjectivity rather than to unconscious material reality (à la Berkey's idealism); and it is a life-idealism because this ontologically prior consciousness is understood not merely as (possibly impersonal, subject-less) thought but as flesh, i.e., as a living self or transcendental body that constantly experiences itself in a diversity of modes. This is what is meant by the term life-idealism.

There are three fundamental theses of Henry's life-idealism: 
(i) life is the foundation of the possibility of the world,

(ii) life assumes a visible, external representation (viz., the empirical body) in its activities in the world, and

(iii) the meaning of the world is that it is the arena in which life pursues the goal of its own perfection and growth.

Once these points are appreciated, it will become evident that Henry's thought is not Gnostic. The goal of this section is to explain each point in turn.

Notably, Jean-François Lavigne also thinks of Henry as something of an idealist. But he supposes that such arguments proposed by Henry as were offered above would seem to commit him to subjective idealism. Yet Lavigne insists that such a thing "certainly was not [his] intention." ${ }^{26}$ He thinks Henry was not trying to be an idealist because he "seems to acknowledge the independent existence of real material bodies in the world." 27 To give one example, Henry says just a little bit after the passage cited above from Incarnation: "As soon as the body shows itself to us in the world, it owes to that mode of appearing certain phenomenological characteristics, all of which derive from exteriority-but never its existence. So one must recognize that all the bodies that are uncovered in the world (whether it is an issue of our own body or any body at all) exist before this uncovering and independently of it." 28 And yet this would seem to be contrary to the assertion cited above according to which "life is the original phenomenalization at the core of being and thus what makes it be." ${ }^{29}$ Is there consequently a contradiction in Henry's thought on this matter?

The question is that of reconciling Henry's idealistic argumentation which founds the world on life, on the one hand, and his admission of the independent existence of bodies apart from their appearing within the world, on the other. This contradiction can be removed if one assumes a particular relation between the world and life, namely: what appears in the world is a representation or external "visible" aspect of an invisible interior life. This would be yet a further sense in which the world is founded upon life. Not only is life the prior condition of the appearance of the world in general, but what appears in the world is precisely an external, visible representation of the invisible reality of life itself; the empirical or visible body is a representation of the transcendental or invisible body or flesh. And insofar as each living self is not brought about in the world but rather by being engendered immanently in the absolute Life of God, it follows that each living self-or more precisely, each "transcendental subjective body" 30 and "invisible, originary corporeity" ${ }^{31}$ —exists prior to its appearing in the world. Thus, when Henry says,

As soon as the body shows itself to us in the world, it owes to that mode of appearing certain phenomenological 
characteristics, all of which derive from exteriority-but never its existence. ${ }^{32}$

he is referring to the transcendental subjective body or flesh which shows itself in the world by means of projecting a representation that is subject to the phenomenological characteristics of world-appearance. This body, the one that stands behind the appearance by which it is represented, does not owe its existence to exteriority, because it is in fact a living self which comes into life as a result of being engendered in the absolute Life of God. It is also worth noting that when Henry says,

So one must recognize that all the bodies that are uncovered in the world (whether it is an issue of our own or any body at all) exist before this uncovering and independently of it.

it is ambiguous whether he refers to any material body whatsoever or only to human or living bodies. If one interprets him as referring to any material body whatsoever, and if one accepts the proposal above that the body which appears in the world is the external, visible representation of the living self, then it would follow that there is a living self for each body encountered in the world-a kind of panpsychism. This would be contrary to the various statements Henry makes to the effect that any number of objects in the world cannot feel or experience anything. It might therefore seem preferable to interpret him to be referring to living human bodies, whether "our own" (pluralis majestatis) or else "any body at all" of some other living being.

There is still a further possibility, although it is admittedly speculative and goes beyond what Henry explicitly says. It should be understood rather a proposal for the development of Henry's system. Just as the empirical human body is a visible, external representation of the transcendental living self that every human being truly is, it would also be open to Henry to suppose that the world itself-not the Earth or the physical cosmos, but this entire itselfapparent milieu of visibility in which individual things appear-is the visible, external "outside" of the absolute Life of God. This would be a further way in which the world and the objects within it could exist apart from and prior to their becoming visible to any particular finite transcendental self. Their existence apart from their being unveiled to the consciousness of any particular finite ego would be the visible aspect of the independence of absolute Life relative to all finite lives which depend on it. Thus, Henry says that "the worldly body is possible only once we have presupposed a flesh already revealed to itself as living flesh in the pathos-filled self-revelation of life." 33 Interpreting the world as God's "body" would thus constitute a different sense in which Life can be "the principle of every thing." ${ }^{\prime 34}$ Not only is life the precondition of appearing of the world, but the world itself, as the absolute horizon of all visibility, is the visible external "aspect" of the absolute Life of God. This would not mean that God could be identified with any particular thing in the world, just as for Henry the true human self is not 
anything that appears in the world. But it would explain how it is that things which do not possess their own individual life might still exist apart from their appearance in the world: they are parts of the visible, external "aspect" of God. Such an interpretation or development of Henry's thought would also provide the world with greater theological significance. One could visualize the idea as follows:

\begin{tabular}{c||c} 
finite living self & visible objective body \\
absolute Life of God & $\begin{array}{c}\text { world as milieu of } \\
\text { visibility }\end{array}$
\end{tabular}

The visible would thus be a mirror of the invisible. For example, the visible body would be in the world in such a way as to represent visibly, externally, the dwelling of the finite living self in the absolute Life of God. And the variegated visible dependence of the worldly body on the world and the other things within it-its need to eat, to drink, to seek shelter, and so onwould be a visible representation of the dependence of the finite living being on absolute Life. ${ }^{35}$

Whatever one says about this more speculative proposal, it is nevertheless clear how to remove the contradiction identified by Lavigne. The empirical body which appears in the world in fact the external, visible representation of the invisible living body, the existence of this latter body being independent of and prior to its being unveiled in the world to any other person in particular. This introduces the second thesis of Henry's "lifeidealism," which is also worth considering some detail.

Henry says that the visible is the representation of the invisible in numerous places. Consider the following passage, which is worth quoting in full:

Our objective worldly body is animated by significations that make it precisely this living body (Leibkörper) whose eyes are eyes that see, whose ears are ears that hear, whose members are movable members moving freely by themselves-all significations borrowed from our original flesh, in whose reality alone the operations aimed at through these various significations draw their reality. Such a body is indeed seen in the world, and the significations that confer it the character of being living are aimed at it too, yet as unreal noematic correlates. But the reality to which they refer-that of our living flesh with all these real operations (of seeing, moving, etc.) - this reality belongs to the sphere of transcendental life's absolute 
immanence; and like it, this is invisible.... As for me, while I perceive my own body in the world, I am this hidden flesh, which is sensing, moving, and suffering, and which endows my objective body with the characteristics it has for me as well as for others. ${ }^{36}$

The empirical body which is visible in the world is a representation of the invisible living self, a representation which is in certain ways adequate and suggestive, even if the life which is represented by the body never itself becomes visible. Thus, one sees a body with eyes, ears, a nose, hands, and so on, understanding this to be a living body belonging to a self that enjoys life. One could even say that the outside corresponds with the inside, as the invisible felt sadness is outwardly projected in the form of a saddened countenance. This is what Henry refers to as the "duplicity of appearing," as for example when commenting on the spirit-body unity as a source of anxiety in Kierkegaard. ${ }^{37}$ And finally, in I Am the Truth: "Any visible appearance is paired with an invisible reality." 38 These passages support the interpretation according to which, for Henry, the body which shows itself in the world in an external, visible representation of the invisible living self which is engendered in the absolute Life of God prior to all appearing in the world.

Recognizing this point makes it possible to address two notorious and controversial dimensions of Henry's thought. On the one hand, there is the largely negative and catastrophic language that Henry uses to describe the mode of appearance of the world and the things which appear within it. Henry writes that what appears in the world is only "an image, a representation, an ob-ject, something opposite us, a phenomenon." ${ }^{39}$ The thing which appears self-externalizes and projects an image of itself. At the same time, this self-externalization takes place in accordance with the ineluctable flow of time, so that there is no frozen present moment of absolute presence but only a ceaseless flow of profiles and aspects. ${ }^{40}$ For this reason, "this coming-into-appearance in the 'outside-itself' of the world signifies that it is the thing itself that finds itself cast outside itself. It is fractured, broken, cleaved in two, stripped of its own reality - in such a way that, now deprived of that reality that was its own, emptied of its flesh, it is no longer outside itself, in the world's Image, but just its own skin, a simple image, in effect, a transparent film, a surface without thickness, a piece of naked externality offered to a gaze that slides over it without being able to penetrate into it or reach anything but empty appearance." ${ }^{41}$ As a result, he says that time and the world "destroy" and "derealize" the things that appear within them. In the world, in that "outside" into which a thing is flung outside of itself in the form of a representational appearance, there is "only, on all sides, death." ${ }^{42}$

This problem dissolves if one holds onto the interpretive proposal being made here, according to which what appears in the outside must be understood as a representation of what exists in life. It is only if one rejects this and limits oneself purely to the world and to its peculiar mode of 
appearing that the nihilism and destruction which Henry mentions follow ineluctably. For Henry, the world is not a site of death and annihilation tout court, but rather the world understood in itself, apart from life. This is in fact what he says: "If everything appeared to us in this way -if there existed no other truth than that of the world - there would be no reality at all anywhere but only, on all sides, death." ${ }^{43}$

On the other hand, there is the insistently repeated affirmation that life does not appear within the world at all but only in its own domain. Henry insists that "Life designates a pure manifestation, always irreducible to that of the world, an original revelation that is not the revelation of an other thing, and does not depend on anything other, but is rather a revelation of self, that absolute self-revelation that is Life itself." ${ }^{44}$ Life is the domain of pure selfrevelation, since, "Life is nothing other than that which reveals itself-not something that might have been an added property of self-revealing, but the very fact of self-revealing, self-revelation as such." ${ }^{45}$ Insofar as the world is the domain in which objects are revealed as being other than the intentional gaze of transcendental consciousness which sees them, it follows that "Living is not possible in the world." 46 Life does not reveal by casting an object outside of itself in the form of a publicly visible representation. Rather, what life reveals is itself, so that the person who is alive precisely as alive experiences him- or herself. As a result, "Life does not cast outside itself what it reveals but holds it inside itself, retains it in so close an embrace that what it holds and reveals is itself." 47 This means that life does not appear within the world: "in the world and in the externality of its 'outside,' no 'Living' is possibleand consequently no livings either." 48

At the same time, although life does not appear in the world, nevertheless the living being does express itself in the world and pursue its goals there, even while its life as such never becomes directly perceptible. This is implied by Henry when he says that "we see living beings but never their life." 49 To say that one sees living beings is to make the visible being a representation of the invisible life, identifying the one with the other. Moreover, the attribution of life to certain beings which appear in the world is founded upon the experience of life in oneself, not on the detection of some visible properties or qualities by which certain objective bodies might distinguish themselves from others which appear in the world..$^{50}$ One attributes to this worldly body an invisible flesh in virtue of which it is truly alive and manifests itself in the world in the precise way that it does. Elsewhere he says, as was cited above, that "this relation of flesh to the body is intelligible only starting from flesh and not starting from the body. . . . Contrary to traditional interpretations, which here include those of contemporary phenomenology, the worldly body is possible only once we have presupposed a flesh already revealed to itself as living flesh in the pathos-filled self-revelation of life." ${ }^{51}$ And elsewhere: "Our body offers us the crucial experience in which the duality of appearing is decisively confirmed. This alone allows us to understand how the body 
truly is a double reality, manifesting itself on the outside, in the outside itself of the world, on the one hand, and lived internally by us, on the other, in Life's pathos-filled self-revelation." ${ }^{22}$ A little further: "the objective body" is "the aspect in which our invisible flesh seems to appear." ${ }^{33}$ And he also straightforwardly notes that the empirical body, "far from defining our actual body (our invisible and indivisible flesh) is only its external representation." 54 Once more, it is clear that for Henry the visible body which appears in the world must be understood as belonging to and representing an invisible life. The life to which this body belongs is invisible and imperceptible, but it is nonetheless there. That is why Henry says, "For me, it is true, this 'I can' and this flesh [which are attributed to some worldly body] are only unreal significations, differentiating his objective body from an ordinary body [lacking life]. This does not alter the fact that this 'I am,' this flesh, and this originary Life are really in him. It is only because this Life really lives in him that these significations are 'true,' signifying a real life, and a real flesh-that his objective body is and can be, for him as for me, a 'living' body." 55

This is how Henry can be understood as proposing a form of "lifeidealism." It consists in at least the following two claims: (i) The visible world is founded upon life insofar as life is the prior condition of the possibility of the world; and (ii) each living self appears within this world through an external, visible representation which is the empirical body. But the question now arises as to the meaning of the world relative to the life which founds it, the subject of the third thesis.

The understanding of the world in Henry's phenomenology of Christianity is problematic for many. Joseph Rivera accuses Henry of being haunted by "the specter of Gnostic dualism: Life contains the truth alone and the world is empty." ${ }^{\prime 6} \mathrm{He}$ also suggests that for Henry "the world [is] without utility, even dangerous." 57 This does not seem true. One would think Henry plainly self-contradictory if he were to assert, in a book which appears in the world, by means of which he intends to communicate his thoughts with others, that there is no truth in the world. Rather, the world is only empty and without truth if it is understood purely in itself, apart from all reference to life. And the danger lies not in the world per se but in the rejection of all other truth except that of the world.

More importantly, for Henry, the world is the arena in which life pursues its own self-actualization and perfection. He says as much in Barbarism by defining "culture" as

an action that life exerts on itself and through which it transforms itself insofar as life is both transforming and transformed. "Culture" refers to the self-transformation of life, the movement by which it continually changes itself in order to arrive at higher forms of realization and completeness, in order to grow. ${ }^{58}$ 
Rivera is therefore mistaken to suggest that for Henry life and the world are polar opposites having nothing to do with another. So also, the remark of Kevin Hart to the effect that (in The Essence of Manifestation) "Henry condemns the world as the horizon of constituted phenomena, the sign of creation and the theatre of history" would also seem to be off the mark. ${ }^{59}$ It is not the world tout court which is empty of truth or dangerous or destitute or worthy of condemnation, but only the world taken on its own, separately from life. One sees; one's seen reflection in the mirror does not see. ${ }^{60}$ Apart from life, the world is indeed an empty wasteland without truth. So also, to forget the truths of life and to plunge oneself into the pure exteriority of the world considered on its own-that indeed is for Henry death and nihilism. But if the world is put in reference to life, then it is understood subordinately as the arena in which living beings express themselves and pursue their purpose of selftransformation in the pursuit of "higher forms of realization and completeness." That is the true and proper meaning of the world, the third thesis of Henry's "life-idealism": the world is the arena for life's selfexpression and self-expansion in growth.

The suggestion being made here is that for Henry the living self is not ultimately intended to fly from the world and to retreat into its own sphere of absolute immanence. Rather, it must live in the world-but in the right way and in the proper knowledge of itself as the son of God. Moreover, this suggestion should not be in the least surprising. Henry defines the transcendental body as the very condition of the possibility of the world in the first place. ${ }^{61}$ The flesh is endowed with a collection of senses which, "though their various sensations, do indeed open us to this world of bodies." 62 The living self is endowed with distinct powers (such as the power to see or to taste or to move) that are constitutive of it as such and which belong to it in virtue of what it is, each power implying a connection to the world and being ordered toward expressing itself precisely in the visibility of the world. ${ }^{63}$ And as he says in I Am the Truth, "Any power the ego possesses is given to it in the very process by which it is engendered as 'me' in the Ipseity of the ArchSon." ${ }^{64}$ The living self is thus plainly ordered toward the world ab initio insofar as it is constituted by various transcendental powers which make the world and its action within it possible. That is why it is absurd to think of the world as by definition devoid of all truth and utterly empty. It is only so when it is not seen in relation and subordinate to life, as the domain in which life is supposed to express itself and pursue its own self-growth and perfection. The world exists for and is defined in reference to life.

Henry therefore proposes a "life-idealism" consisting in the following theses: (i) the foundation of the visible world on life; (ii) the manifestation of invisible life in the world through the form of an empirical body; (iii) the meaning of the world as the domain in which life pursues its own selfactualization and perfection. 


\section{Accusations of Gnosticism}

Now that the contours of Henry's life-idealism have been made explicit, it will be possible to respond to common objections and misconceptions brought forth by his theological critics. Contrary to what they say, Henry is neither a monist, nor a dualist, nor a pantheist, nor a world-denier, nor a faithrejecting proponent of a special gnōsis.

Joseph Rivera ${ }^{65}$ and Amber Bowen, ${ }^{66}$ drawing from Emmanuel Falque, ${ }^{67}$ accuse Henry of being a "carnal monist" in a "qualified sense" because he says things like this:

In my living flesh I am given to myself and thus I am a meI am myself. But it is not me who has given me to myself: it is not me who joins me to myself. I am not the gate, the gate what opens me to myself, nor am I the grass, the grass that allows my flesh to grow. In my flesh I am given to myself, but I am not my own flesh. My flesh, my living flesh, is Christ's. ${ }^{68}$

But one could just as well call Thomas Aquinas an "existential monist" in a "qualified sense" because he affirms that every ens receives its existence (esse) and everything else that makes it up from God, who is tantum esse. ${ }^{69}$ The difference is only that for Thomas the fundamental ontological condition is esse, whereas for Henry it is life. ${ }^{70}$ If Thomas is not a monist, then neither must Henry be considered such; but if Henry is a monist in some sense, then so might be Thomas. In a case like this, the application of the label "monist" here seems to have more connotative force than actual substance.

Bowen says that "Henry's reading of the doctrine of creation dramatically illustrates the gnostic impulses throughout his signature version of ontological monism," and that "In order to hold onto his philosophical aversions, $\mathrm{He}$ [sic] tailors the doctrine of creation beyond recognition." ${ }^{71}$ Kevin Hart, too, accuses Henry of Gnosticism for saying that the soul is uncreated. ${ }^{72}$ Falque suggests that on this point Henry's work as a whole is negated insofar as he fails to recognize "a distance in the relation of the human to God ... that is not identical to the distance of sin."73 But when Henry denies that the human being is created, he means to deny that the human being is totally external to God in such a way that he could continue to exist apart from God, just as a house can exist apart from its creator. ${ }^{74}$ Now, it is true that for Henry there is a certain moment of "ontological overlap" or "contact" between the human being and the absolute Life of God..$^{75}$ But Henry also constantly asserts a distinction between "a finite life like ours [and] the infinite Life which is that of God." ${ }^{76}$ Hefty makes this same point against Falque. ${ }^{77}$ One could thus describe Henry (but also very many a thinker, for that matter) just as well as a "qualified monist" and as a "qualified dualist." Henry means simultaneously to assert that the human being cannot exist or enjoy life apart 
from being continually engendered in the absolute Life of God, so that there is a moment of "ontological overlap," as well as that the finite human being is irreducibly him- or herself, distinct from God.

The reason why Henry asserts a moment of "ontological overlap" between the finite living being and the absolute Life of God is that sharp distinctions between things are only evident in the "outside" of the world, where one thing is seen here and another thing is seen over there. Life does not appear in the world, and the finite living being cannot be separated from God without disappearing altogether. In other words, the human being does not enjoy "existential inertia." 78 Thus, the language used to describe the simultaneous sameness and difference between the finite living self and the absolute Life of God will naturally generate certain tensions. One can disagree with Henry on this point, but he is not rightly called a "monist" given that he would agree with the following statements: the finite self is really caused by but not reducible to God's self; the finite life is really received from but not reducible to the infinite life of God; the real ignorance of the finite living self is not God's ignorance; the real sin of the finite living self is not God's sin; and so on.

Not only is Henry called a "monist," but he is also called a "dualist." As was mentioned earlier, Rivera considers that Henry is haunted by "the specter of Gnostic dualism: Life contains the truth alone and the world is empty," and claims that for Henry "the world [is] without utility, even dangerous." ${ }^{79}$ But this also is plainly not true. Once more, for Henry the world is empty and without truth only if it is understood purely by itself, apart from all reference to life. And the danger is not in the world per se but rather in the rejection of all other truth except that of the world. This is how one should understand the passage referenced by Rivera in which Henry says: "The man of the world is merely an optical illusion. 'Man' does not exist." ${ }^{80} \mathrm{He}$ is referring to the worldly, empirical, objective body understood in abstraction from all reference to invisible life. The man of the world, understood merely as a visible object, is an optical illusion because there is discernible within it no individuality or ipseity. ${ }^{81}$ Rather, Henry insists that "There is Ipseity only in life. Ipseity belongs to the essence of Life and to its phenomenality as well. It is born in the process of self's phenomenalization, in the process of its pathétik self-affection, and as the very mode in which that self-affecting comes about." 82 In other words, the ipseity of a person is not an empirically detectable property, so that to reduce the person to the empirically detectable is to do away with his or her ipseity. And something similar can be said about the complaint of Jack Louis Pappas, who claims that for Henry "the body cannot 'appear' without being reduced to a corpse." ${ }^{83}$ It would seem more accurate to say that, for Henry, only the visible body reduced to its pure visibility, understood apart from all reference to invisible life, cannot be anything but a corpse. The visible appearance (body) must be paired with an invisible reality (flesh, life). The truth of a person is found in the invisibility of 
life, whereas the body that appears in the world must be understood as only an external, visible representation of that life and of its efforts to pursue its goals within the world.

So also, Henry is sometimes called a "pantheist." Rivera cites Jad Hatem who accuses Henry of "Gnostic dualism" insofar as "the invisible depths of the soul and God 'are irreducible in Henry, a fact that does not save him from pantheism which maintains the identity of the nature of human life with divine life, homoousia, a fact for which Clement of Alexandria reproached the Gnostics.'"84 (Is the accusation of dualism or pantheism?) Rivera also objects that, once God and the human being are defined in terms of life, "all language of 'creaturehood or 'finitude' or 'human nature' in Henry is no longer justified since human nature is already divine in essence." ${ }^{85}$ But one might make an accusation of pantheism (or monism, or dualism, or whatever) against those who say that God and the human being both exist, or are personal, or rational, or conscious, etc. ${ }^{86}$ Indeed, one could just as well accuse Berkeley of pantheism for saying that God and the human being are both spirits or minds. ${ }^{87}$ The idea seems to be that applying one and the same category to God and to the human being implies pantheism. So also, for Henry, "God being Life, the human is a living being." 88 But if Berkeley is not a pantheist for distinguishing between the finite human spirit and the eternal Spirit of God, then the same can be said for Henry. Indeed, pantheism is avoided precisely by distinguishing between God as the paradigmatic possessor of the fundamental ontological condition and the human being as a finite participant in that condition. ${ }^{89}$ Thus, Hefty is correct: "These charges seem entirely misguided, because as [sic] Henry affirms always and everywhere only one absolute life, and ultimately also one living proper to [absolute] life." 90 At best, Henry could be described as something of a panentheist.

To demonstrate the non-monism and non-pantheism of Henry, it suffices to cite the following passage from Incarnation:

But in Christianity there is something radically original in relation to the other great forms of spirituality. This absolute unity between all living Selves, far from signifying or implying the dissolution of the individuality of each one, is on the contrary constitutive of it, in as much as each of them is joined to himself or herself in the phenomenological effectuation of Life in its Word, and generated in themselves as this irreducibly singular Self, irreducible to any other. This is one of the decisive meanings of the ageless utterance of Meister Eckhart: "God engenders himself as myself.". . . Thus one of the great paradoxes of Christianity is clarified. Maintaining each one, the most humble, and the most insignificant, in its own irreducibly singular individuality, in its condition as a transcendental Self that is by essence this one or that one forever-far from needing 
or being able to be overcome or abolished anywhere, this alone can snatch humankind from nothingness. ${ }^{91}$

Rivera therefore seems mistaken when he writes that "Henry's anthropology succumbs to a peculiar kind of theological monism: an absolute absorption of 'myself' as this particular self within the universal presence of Christ, a kind of absolute transcendental Christology." 92 This is contrary to what Henry explicitly says above, in which such an absorption or dissolution is explicitly rejected.

In addition to accusing him of monism, dualism, and pantheism, Rivera also suggests that Henry wishes to "deny the world altogether," that his analysis of the world and its mode of making-apparent "can be said to construct the world as a kind of 'demonic power' that will consume and annul all real and imagined totalities," and that "a kind of nihilism can be found at its core." ${ }^{\prime 93}$ But then Rivera contradicts himself when he later concedes that "Henry does not deny or negate the world." ${ }^{94}$ He qualifies his earlier reading as follows: "The world, as the stage that displays visible objects and objective bodies, does not disclose the essential precisely because it masks the essential-the world must exist in order to cover over the invisible. And in its veiling of the interior self, the world shows falsehood, literally acting deceitful about what is really the thing itself." ${ }^{95}$ But this interpretation is exaggerated. The discussion above made clear that what appears in the world is for Henry a visible, external representation of an invisible reality. The world does not lie; it just does not tell the whole story. The falsehood arises only by privileging the visible to the exclusion of the invisible.

Alongside world-denial, Rivera further accuses Henry of "Gnostic escapism." 96 But this argument also fails. As was noted earlier, Henry's conception of things if anything makes it impossible to escape from the world. The world is the stage on which life is visibly represented. The living transcendental self is naturally endowed with several powers by which it is ordered to the world from the beginning. Indeed, the world is the arena within which life pursues its self-actualization and perfection. Thus, there is no world-escapism in Henry. It is true that, for Henry, the true condition of the human being can only be appreciated when one turns away from the world to one's own condition as a finite (and thus utterly dependent) living self. ${ }^{97}$ But this is not world-denial. It is only the consequence of Henry's lifeidealism according to which the world must be understood with reference to life, rather than the other way around.

Finally, James Hart complains that Henry's understanding of Christianity turns faith into a sort of special gnōsis rather than the pistis of Scripture, which he understands as "the substance of things hoped for, the evidence of things unseen" (Heb 11:1). ${ }^{98}$ But this too does not seem correct. In the first place, the Epistle to the Hebrews enjoins pistis meaning faithfulness and perseverance in the life of a Christian, such as was exemplified by "so 
great a cloud of witnesses" (Heb 12:1). But the Epistle to the Hebrews also takes for granted that "in these last days [God] has spoken to us by a Son" (Heb 1:1-2). It is therefore enjoining faithfulness to a truth which is not taken as a matter of mere faith but rather is asserted as an item of knowledge. Indeed, it does not make sense to be enjoined to be faithful to something that one does not know to be true. And in the second place, there is a long-standing tradition in Christian theology which sees the essence of Christian faith as a kind of knowledge. For example, John Calvin defines faith as "a firm and certain knowledge of God's benevolence toward us, founded upon the truth of the freely given promise in Christ, both revealed to our minds and sealed upon our hearts through the Holy Spirit." 99 So also Henry: "II believe in Christ' means: 'I am certain of the truth which is in Him.'" 100 Thus, Henry is not discontinuous with the broader Christian tradition in understanding faith as a form of knowledge.

\section{Concluding Remarks}

This article has attempted to show that Michel Henry is not a Gnostic of any variety: neither a monist, nor a dualist, nor a pantheist, nor a worlddenier, nor a proponent of a special gnōsis in place of a Christian sense of faith. Henry's phenomenology must rather be understood as a form of lifeidealism according to which (i) life is the foundation of the world; (ii) life assumes a visible, external representation (i.e., the empirical body) in its activities in the world; and, (iii) the meaning of the world is that it is the arena in which life pursues the goal of its own perfection and growth. Once it is seen in this light, against his theological critics, his thought can be seen not to be Gnostic. He is not a monist because he constantly affirms a real and irreducible distinction between the finite life of the finite living self and the absolute Life that is God. He is not a dualist because the world and life are not for him two utterly disparate domains of appearance. Rather, what appears in the world is precisely the external, visible representation of an invisible life. He is not a pantheist because, once more, he always distinguishes between God and the finite living being, even as He recognizes a certain moment of ontological "overlap" or "contact" between the two. At best he is a panentheist. And he is certainly not a world-denier since for him the living being is naturally endowed with various powers which essentially and inescapably order it to the world. Moreover, the world is precisely the arena within which life pursues its self-actualization and perfection. Finally, Henry is not a faith-denying proponent of a special gnōsis. Rather, his conception of faith is consonant with the understanding of faith as knowledge in the Reformed tradition, for example, of Calvin. 
1 The trilogy, in order according to their original publication in French, comprises Michel Henry, I Am the Truth: Toward a Philosophy of Christianity, trans. Susan Emanuel (Stanford: Stanford University Press, 2003); Incarnation: A Philosophy of Flesh, trans. Karl Hefty (Evanston: Northwestern University Press, 2015); and Words of Christ, trans. Christina M. Gschwandtner (Grand Rapids, MI: Eerdmans, 2012).

${ }^{2}$ Not all theological readers of Michel Henry are equally critical. See the favorable discussion in John Behr, John the Theologian and His Paschal Gospel: Introduction to Theology (New York: Oxford University Press, 2020).

${ }^{3}$ See Michel Henry, The Essence of Manifestation, trans. Girard Etzkorn (The Hague: Martinus Nijhoff, 1973); "The Four Principles of Phenomenology," trans. Joseph Rivera and George E. Faithful, Continental Philosophy Review 48 (2015): 1-21. This insight also forms the basis of his discussion in Michel Henry, Genealogy of Psychoanalysis, trans. Douglas Brick (Stanford: Stanford University Press, 1993). See also the discussion in Karl Hefty, "Phenomenality or Revelation: Michel Henry's Approach to Christianity," Analecta Hermeneutica 8 (2016): 196-217.

${ }^{4}$ Henry, Words of Christ, 70-71.

${ }^{5}$ Michel Henry, Material Phenomenology, trans. Scott Davidson (New York: Fordham University Press, 2008), 3.

${ }^{6}$ See the discussion in Brian Harding, “Auto-Affectivity and Michel Henry's Material Phenomenology," The Philosophical Forum 43, no. 1 (2012): 91-100.

${ }^{7}$ Hefty, "Phenomenality or Revelation," 208.

${ }^{8}$ Henry, Incarnation, 110.

${ }^{9}$ Henry, Incarnation, 36.

${ }^{10}$ Michael Kelly, “Disposession: On the Untenability of Michel Henry's Theory of SelfAwareness," Journal of the British Society for Phenomenology 35, no. 3 (2004): 261 82,278 . Although the comparison cannot be pursued here, a very similar argument seems to be put forth from a more Hegelian perspective by Sebastian Rödl, SelfConsciousness and Objectivity: An Introduction to Absolute Idealism (Cambridge, MA: Harvard University Press, 2018).

${ }^{11}$ Compare Henry with the interpretation of Thomas Aquinas's argument from the De Ente et Essentia in Gaven Kerr, Aquinas's Way to God: The Proof in De Ente et Essentia (New York: Oxford University Press, 2015). See also Steven Nemes, “Two Ways to God in Thomas Aquinas and Michel Henry," Journal for Continental Philosophy of Religion 3, no. 2 (2021) : 164-187.

12 Henry, I Am the Truth, $152 \mathrm{ff}$. 
13 Henry, Incarnation, 184.

${ }^{14}$ Henry, Words of Christ, 97.

${ }^{15}$ Henry, Incarnation, 122, 168-72.

${ }^{16}$ Henry, Words of Christ, 96.

17 Henry, Words of Christ, 82.

18 See Nemes, "Two Ways to God."

${ }^{19}$ Henry, Words of Christ, 119, emphasis original.

20 Henry, I Am the Truth, 23.

${ }^{21}$ Henry, Words of Christ, 82, emphasis original.

22 See Andreas Gonçalves Lind, “God's Presence within Henry’s Phenomenology of Life: The Phenomenological Revelation of God in Opposition to Plantinga's Affirmation of God's Existence," Religions 9 (2018): 1-10.

${ }^{23}$ For this reason, Kevin Hart seems mistaken when he writes that "God, for Henry, is inaccessible darkness." See Hart, "Inward Life," 96. Consider also the citation of Meister Eckhart's "Gott wissender mensch" in Michel Henry, "Speech and Religion: The Word of God," in Dominique Janicaud, Jean-François Courtine, Jean-Louis Chrétien, Jean-Luc Marion, Michel Henry, and Paul Ricœur, Phenomenology and the "Theological Turn": The French Debate (New York: Fordham University Press, 2000), $217-41,226$ ${ }^{24}$ Henry, I Am the Truth, ch. 8.

25 This is a classic response to idealist-style arguments. For an example, see A. C. Ewing, Idealism: A Critical Survey (New York: Routledge, 2012 [1934]), 15-16. In response, Henry could in principle argue as follows. He says: "What could I know about a being that could not appear?"; Material Phenomenology, 3. Consider that, in order to know whether a cat is able to leap a certain distance, one must see it doing this. In the same way, to know that something can exist apart from all appearing, it is necessary to see it existing apart from all appearing. But this is a contradiction, since one would be seeing it and thus it would appear. Therefore, it cannot be known that some object can exist apart from all appearing whatsoever.

26 Jean-François Lavigne, “The Paradox and Limits of Michel Henry's Concept of Transcendence," International Journal of Philosophical Studies 17, no. 3 (2009): 37788, 382; emphasis added.

27 Lavigne, "Paradox and Limits," 386.

${ }^{28}$ Henry, Incarnation, 121, emphasis original.

${ }^{29}$ Henry, Material Phenomenology, 3, emphasis added.

30 Henry, Incarnation, 36, emphasis added.

${ }^{31}$ Henry, Incarnation, 120, emphasis added. 
32 Henry, Incarnation, 121, emphasis added.

33 Henry, Incarnation, 136, emphasis removed.

${ }^{34}$ Henry, Material Phenomenology, 3.

35 The idea of the world as the "body of God" is also proposed Sally McFague, but there is no intention here to assimilate Henry's phenomenology of Life to McFague's own perspective as expressed in works such as Models of God: Theology for an Ecological, Nuclear Age (Minneapolis: Fortress Press, 1987), ch. 3.

${ }^{36}$ Henry, Incarnation, 199-200.

${ }^{37}$ Henry, Incarnation, 195.

38 Henry, I Am the Truth, 258.

${ }^{39}$ Henry, I Am the Truth, 17.

${ }^{40}$ Henry, I Am the Truth, 19.

${ }^{41}$ Henry, I Am the Truth, 18.

42 Henry, I Am the Truth, 20.

${ }^{43}$ Henry, I Am the Truth, 20, emphasis added.

${ }^{44}$ Henry, I Am the Truth, 34.

${ }^{45}$ Henry, I Am the Truth, 27, emphasis removed.

${ }^{46}$ Henry, I Am the Truth, 30, emphasis removed.

${ }^{47}$ Henry, I Am the Truth, 30.

${ }^{48}$ Henry, I Am the Truth, 71, emphasis removed; cf. 40-41.

${ }^{49}$ Henry, I Am the Truth, 40.

${ }^{50}$ Henry, I Am the Truth, 40-50.

${ }^{51}$ Henry, Incarnation, 136.

52 Henry, Incarnation, 151.

53 Henry, Incarnation, 196.

54 Henry, Incarnation, 176, emphasis added.

${ }^{55}$ Henry, Incarnation, 200.

56 Joseph M. Rivera, "Generation, Interiority, and the Phenomenology of Christianity in Michel Henry," Continental Philosophy Review 44 (2011): 205-35, 223.

${ }^{57}$ Rivera, "Generation, Interiority, and the Phenomenology of Christianity," 223.

${ }^{58}$ Michel Henry, Barbarism, trans. Scott Davidson (New York: Continuum, 2012), 5.

${ }^{59}$ Kevin Hart, “Inward Life," in Jeffrey Hanson and Michael R. Kelly, eds., Michel Henry: The Affects of Thought (New York: Continuum, 2012), 105.

${ }^{60}$ Henry, Incarnation, 154.

${ }^{61}$ Henry, Incarnation, 110 . See the passage cited above.

62 Henry, Incarnation, 147.

${ }^{63}$ Cf. Henry, Incarnation, 136-46. 
${ }^{64}$ Henry, I Am the Truth, 138.

${ }^{65}$ Rivera, Contemplative Self, 201.

${ }^{66}$ Amber Bowen, "How to Cross the Rubicon without Falling in: Michel Henry, Søren Kierkegaard, and New Phenomenology," International Journal of Philosophy and Theology 80, nos. 4-5 (2019): 465-81.

67 Emmanuel Falque, "Is There a Flesh without Body? A Debate with Michel Henry," Journal of French and Francophone Philosophy/Revue de la philosophie française et de langue française 24, no. 1 (2016): 139-66, $159 f f$.

${ }^{68}$ Henry, I Am the Truth, 116, emphasis added.

69 See John F. X. Knasas, Thomistic Existentialism and Cosmological Reasoning (Washington, DC: Catholic University of America Press, 2019).

70 See Nemes, "Two Ways to God."

71 Bowen, "How to Cross the Rubicon," 470. See also Rivera, "Generation, Interiority, and the Phenomenology of Christianity," 219-22.

72 Hart, “Inward Life," 103.

${ }^{73}$ Falque, "Is There a Flesh without a Body?," 160.]

${ }^{74}$ Henry, Words of Christ, 84.

${ }^{75}$ Henry, Incarnation, 229.

${ }^{76}$ Henry, Words of Christ, 82.

77 See Karl Hefty, “Is There a Body without Flesh?,” Journal for Continental Philosophy of Religion 3, no. 1 (2021): 27-48, 41-42.

78 See Hefty, "Is There a Body without Flesh?," 42.

${ }^{79}$ Rivera, "Generation, Interiority, and the Phenomenology of Christianity," 223.

${ }^{80}$ Henry, I Am the Truth, 124.

81 This is a topic of discussion surrounding the "no-self" doctrine of Buddhism. See William F. Vallicella, "Can the Chariot Take Us to the Land of No Self?" The Proceedings of the Twenty-First World Congress of Philosophy 9 (2006): 29-33; and “No Self? A Look at a Buddhist Argument," International Philosophical Quarterly 42, no. 4 (2002): 453-66.

82 Henry, I Am the Truth, 124, emphasis added.

83 Jack Louis Pappas, "Between the Flesh and the Lived Body: Henry and Falque on the Phenomenology of Incarnation," Journal for Continental Philosophy of Religion 2 (2020): 73-90, 88.

84 Jad Hatem, Le sauveur et les viscères de l'être: Sur le gnosticisme et Michel Henry (Paris: L'Harmattan, 2004), 82, cited in Rivera, Contemplative Self, 160.

${ }^{85}$ Rivera, Contemplative Self, 125. 
${ }^{86}$ For example, Dumitru Stăniloae emphasizes "person" and "conscious" as common categories applying both to God and to the human being in his Orthodox Dogmatic Theology: The Experience of God, vol. 1, Revelation and Knowledge of the Triune God, (Holy Cross Orthodox Press, 1998), ch. 1.

87 George Berkeley, Of the Principles of Human Knowledge I, §94, in Principles, Dialogues, and Philosophical Correspondence, ed. C. M. Turbayne (New York: The Bobbs-Merrill Company, 1965).

88 Henry, Words of Christ, 86.

${ }^{89}$ See Nemes, "Two Ways to God."

90 Hefty, "Phenomenality or Revelation," 212.

${ }^{91}$ Henry, Incarnation, 248.

92 Rivera, Contemplative Self, 153.

93 Joseph Rivera, The Contemplative Self after Michel Henry: A Phenomenological Theology (Notre Dame: Notre Dame University Press, 2015), 70.

${ }^{94}$ Rivera, Contemplative Self, 89.

${ }^{95}$ Rivera, Contemplative Self, 90.

${ }^{96}$ Rivera, Contemplative Self, 169.

${ }^{97}$ Henry, Words of Christ, 82-83.

98 James G. Hart, “Michel Henry's Phenomenological Theology of Life: A Husserlian Reading of C'est moi, la verité," Husserl Studies 15 (1999): 183-230, 195.

99 John Calvin, Institutes of the Christian Religion, vol. 1, trans. Ford Lewis Battles, ed. John T. McNeill (Louisville: Westminster John Knox Press, 2006), 551 (Book III, chapter II, section 7); emphasis added. See also Kevin Diller, Theology's Epistemological Dilemma: How Karl Barth and Alvin Plantinga Provide a Unified Response (Downers Grove: IVP Academic, 2014). But see the critique of Martin Westerholm, "Analytic Theology and Contemporary Inquiry," International Journal of Philosophy and Theology 80, no. 3 (2019): 230-54.

100 Henry, Incarnation, 260. 